\title{
COMPARATIVE STUDIES OF THE BIODIESEL FUEL JET DEVELOPMENT DYNAMICS IN COMMON RAIL AND CONVENTIONAL DESIGN FUEL SYSTEMS
}

\author{
Sergey P. KULMANAKOV ${ }^{1}$, Sergejus LEBEDEVAS ${ }^{2 \#}$, Sergey S. KULMANAKOV², \\ Nadežda LAZAREVA ${ }^{4}$, Paulius RAPALIS ${ }^{5}$ \\ ${ }^{1}$ Dept of Internal Combustion Engine, Altai State Technical University, Barnaul, Russia \\ ${ }^{2,4}$ Dept of Marine Engineering, Klaipeda University, Lithuania \\ ${ }^{3}$ ABIT Ltd, Saint-Petersburg, Russia \\ ${ }^{5}$ Marine Research Institute, Klaipeda University, Lithuania
}

Received 26 January 2018; revised 27 February 2018; accepted 1 May 2018

\begin{abstract}
The results of comparative diesel and biodiesel (Rapeseed oil Methyl Ester (RME) and Rapeseed Oil (RO)) fuel jet structure studies by optical scanning method are presented. There is an interrelation between the dynamics of fuel jet development by the Common Rail (CR) with single-phase injection and Conventional Design System (CDS) and the parameters of mixture formation, which are typical for transferring the operation of the Diesel Engine (DE) from mineral diesel to RME and RO. The structure of the Diesel Fuel (DF) jet is significantly more heterogeneous by the size and number of droplets in CDS in comparison with CR. From the moment of the injection the presence of zones less saturated with fuel contributes to a relatively short induction period $-5^{\circ} \mathrm{ca}$. compared to $11 \ldots 12^{\circ} \mathrm{ca}$. in the CR system. Using RME in the CR system in comparison with DF, increases the heterogeneity of the fuel jet, thereby causing a shorter (by $1 \ldots 2^{\circ} \mathrm{ca}$.) induction period in the whole investigated range of injection pressures of $60 \ldots 160 \mathrm{MPa}$. The injection of a non-heated RO is accompanied by the shape and structure fluctuations of the fuel jet. RO heating to $65^{\circ} \mathrm{C}$ stabilizes the structure of the jet and increases the share of less saturated zones. Promising way of use for the optical scanning method in the mathematical modelling of the DE working process is proposed.
\end{abstract}

Keywords: diesel engine, common rail, conventional design system, fuel system, fuel jet structure, rapeseed oil methyl ester, rapeseed oil.

\section{Abbreviations}

AltSTU - Altai State Technical University (Russia);

CDS - Conventional Design System;

$\mathrm{CN}$ - Cetane Number;

CR - Common Rail;

DE - Diesel Engine;

DF - Diesel Fuel;

FAEE - Fatty Acids Ethyl Ester;

FAME - Fatty Acids Methyl Ester;

KU - Klaipèda University (Lithuania);

LIF - Laser-Induced Fluorescence;

RME - Rapeseed oil Methyl Ester;

RO - Rapeseed Oil;

SMD - Sauter Mean Diameter.

\section{Introduction}

The limited world reserves of petroleum fuels, increasing consumption and greenhouse gas emissions contribute to transfer of the $\mathrm{DE}$ to alternative renewable fuels - biodiesel. In the EU countries, the dynamics of this substitution is regulated by a number of European Parliament directives (EC 2005, 2009). In Directive 2009/28/EC it is planned to reach $10 \%$ share of renewable energy in the transport sector by 2020. The transport sector strategic development document for the EU countries, White Paper, also calls for use of biofuel in the transport sector instead of mineral fuel (EC 2011).

In the Western countries, certified methyl and ethyl esters of vegetable oil fatty acids (FAME, FAEE) are used as biodiesel. For example, in EU countries - RME certified in accordance with the EN 14214:2009.

${ }^{*}$ Corresponding author. E-mail: nadezda.zamiatina@ku.lt

\#Editor of the TRANSPORT - the manuscript was handled by one of the Associate Editors, who made all decisions related to the manuscript (including the choice of referees and the ultimate decision on the revision and publishing).

Copyright @ 2019 The Author(s). Published by VGTU Press

This is an Open Access article distributed under the terms of the Creative Commons Attribution License (http://creativecommons.org/licenses/by/4.0/), which permits unrestricted use, distribution, and reproduction in any medium, provided the original author and source are credited. 
In countries of Eastern Europe (Belarus, Ukraine, Russia, etc.) (Markov et al. 2011; Zhosan et al. 2012), and also partially in the EU countries (Labeckas, Slavinskas 2009), pure vegetable oils, primarily $\mathrm{RO}$ and their mixtures with petroleum diesel, are often used as biodiesel. Their production technology is much less expensive, and the cost of pure vegetable oils is less than that of FAME.

One of the most important tasks is to optimize the parameters of engine working process operating on biodiesel (RME, RO). Part of this task is the study and optimization of fuel injection parameters and characteristics. The relevance of solving this task is due to the differences in the physical-chemical properties of RME and especially RO from diesel: density, viscosity, surface tension, evaporation, etc. (Kegl et al. 2008; Markov et al. 2013).

For the operated DE fleet, this task is solved by optimizing the adjustment parameters and design of the fuel system and combustion chamber: selecting the optimum injection pressure (CR system), nozzle atomizer design (diameter, number of spray holes) and preliminary heating of RO in the CDS (Marchenko et al. 2005).

The relevance of the research and optimization of biodiesel injection in DE causes not only a wide range of research aspects, but also development of new research methods. The main parameters of the liquid fuel atomization quality in the DE combustion chamber are: the dispersion composition and distribution of fuel concentrations, angle, velocity and length of fuel jet. The most informative for optimizing the fuel supply system parameters, but at the same time complicated, are the methods for studying the fineness and homogeneity of fuel atomization (Mollenhauer, Tschöke 2010; Ashgriz 2011; Lyshevskij 1981; Lewińska, Kapusta 2017).

At present, optical methods are successfully used for measuring the fineness of atomization and concentration of droplets in a fuel jet (Van de Hulst 1981; Kerker 1969). Lewińska and Kapusta (2017) studied the parameters of the microstructure of DF spray using the LIF method in combination with Mie scattering. Based on the obtained imaging diesel spray form and distribution of droplets in the gas phase were determined. Pastor et al. (2012) used this method to determine the SMD, but to enhance the fluorescence effect, indicator Rhodamine B was added to the fuel. The method is widely used by other researchers Li et al. (2011) investigated the characteristics of the swirl spray. Linne (2013) and Linne et al. (2006) developed an optical technique called ballistic visualization when light passes through a cloudy environment, the photons that make up this light experience a different amount of scattering. Sedarsky et al. (2009) and others demonstrated that from ballistic images it is possible to obtain the speed data of the spray.

One of the most accurate methods for determining the droplet size is a method of laser diffractoscope. Its working principle is based on measuring the scattering of a laser beam. The angle at which the drop disperses light is inversely proportional to its diameter. This method was used by Klyus et al. (2013) and Krause, Klyus (2013) to determine the distribution of droplets in the jet of DF and DF mixtures with biocomponents. The same method proved itself very good with the establishment of SMD and distribution of droplets in the residual fuel jet, despite the opacity of the tested fuel (Klyus, Zamiatina 2017). However, the fineness and dispersion analysis of the atomized fuel is carried out in a fixed section of the jet. Therefore, to evaluate the structure of the entire jet, it is necessary to repeat the experiment many times.

To determine the speed, angle, and length of the fuel jet, the method of high-speed photography is most often used. Wang and others (Wang et al. 2017) used the method of high-speed photography to measure the injection angle and speed of four types of fuels.

The article presents comparative studies of the jet development characteristics of the DF, RME and RO in CR with single-phase injection and CDS fuel systems by optical sensing method, developed by scientists from the AltSTU (Es'kov et al. 2014).

This article presents the results of the next stage of joint research by scientists from AltSTU and KU into the use of biodiesel in DE (Lebedevas et al. 2006a, 2006b; Kulmanakov et al. 2009, 2016).

The objectives of the research were:

- determination of fuel jet structure and dynamics development features in the fuel supply systems under study in correlation with the self-ignition and combustion dynamics of diesel and alternative fuels;

- study of the influence of fuel supply system design and adjustment parameters on the structure and development dynamics of the fuel jet;

- evaluation of the viable optical sensing method uses in the research of fuel supply system characteristics in DEs.

\section{Research methods and subjects}

\subsection{Optical sensing method}

The scheme of the high-speed photography stand, used for the optical sensing method, is shown in Figure 1. Fuel is supplied into the injector at a given pressure: from 60 to $180 \mathrm{MPa}$ in the $\mathrm{CR}$ system and $65.0 \mathrm{MPa}$ in the CDS system $\left(1750 \mathrm{~min}^{-1}\right)$. During spraying, the fuel jet moves along the surface of the screen, illuminated from the inside by a light source. High-speed video camera (video shooting frequency - 7042 frames per second) records the temporal development of a fuel jet. Synchronizer coordinates the nozzle opening moments and start of video recording, the control unit coordinates the operation of the camera, computer and injector. More detailed scheme of the stand, as well as the scheme of optical measurement and screen (Figure 2) is described in the work of the authors (Kulmanakov et al. 2012).

Experimental studies of the fuel jet structure dynamics were carried out by the evaluation of brightness changes in the fuel jet zones. Brighter zones correspond to a greater density of fuel jet zones with smaller reference numbers. 


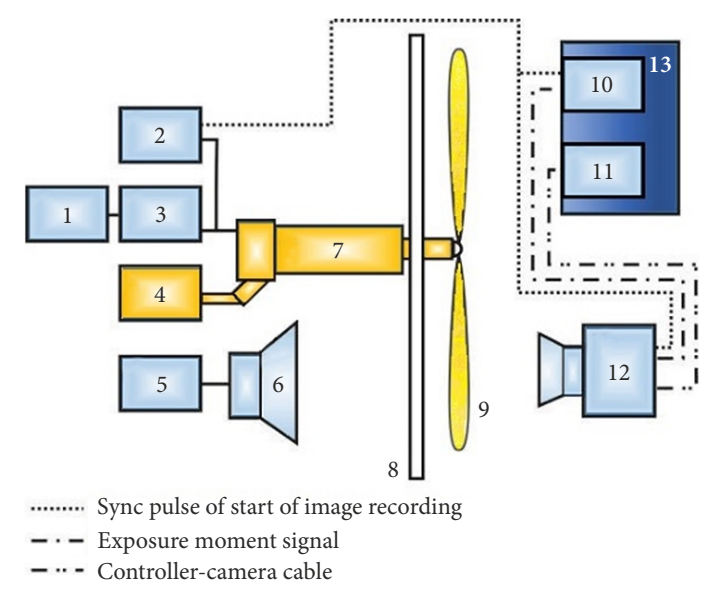

Figure 1. Schematic diagram of a high-speed video shooting stand for determining the parameters of a fuel jet: 1 - electronic engine control unit; 2 - synchronization devices; 3 - control block; 4 - fuel tank; 5 - power supply unit; 6 - light source; 7 - nozzle; 8 - screen; 9 - fuel jet; 10 - ADC LA 1.5 PCI; 11 - controller board; 12 - high-speed video camera "Videosprint"; 13 - PC

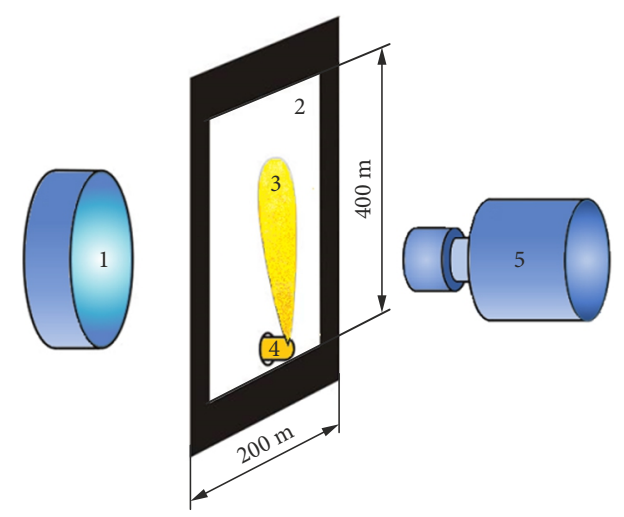

Figure 2. Optical measurement scheme and screen design: 1 - lamp; 2 - scattering screen; 3 - fuel jet; 4 - nozzle; 5 - high-speed video camera

a)

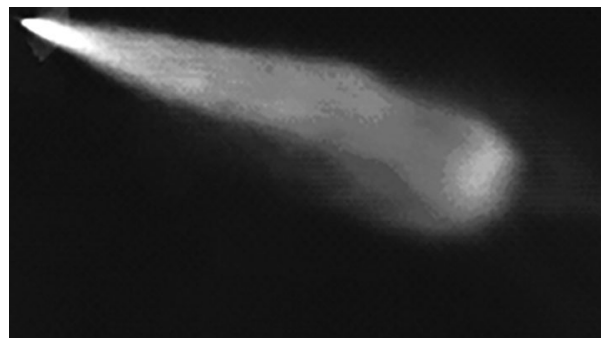

b)

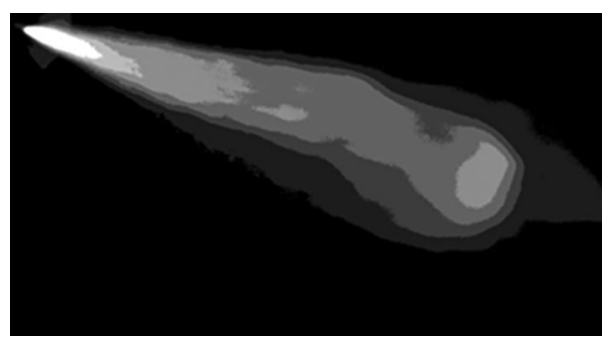

Figure 3. Fragments of recording the image of the fuel atomization process (image inverted): a - initial image (exposure time $35.5 \mu \mathrm{s} ; \mathrm{b}$ - brightness zones, allocated by the computer program on the image using the threshold segmentation method
An example of image processing of the fuel atomization process using the original computer program (Es'kov, Gibel'gauz 2011) is shown in Figure 3. The figure shows the instantaneous initial image of the jet, recorded by high-speed filming, and the brightness zones allocated by software, using the threshold segmentation method.

\subsection{Test fuels}

Comparative measurements were performed using mineral diesel according to GOST R 52368-2005 and EN 590:2009, biodiesel RME according to EN 14214:2009 and RO according to GOST R 53457-2009. The main physical-chemical properties of the tested fuels are given in Table 1.

The brightness of the zones, which is the basis of the optical scanning method, evaluates both the size of the droplets and the density of the droplets in the air. Based on fundamental research of the fuel jet (Lyshevskij 1971; Mollenhauer, Tschöke 2010; Ashgriz 2011), these phenomena are in close interrelation. The fragmentation of droplets into smaller ones mainly occurs in the peripheral zones of the fuel jet's middle part, which interacts intensely with the air flow. In the inner region of the jet along the axis large-sized fuel droplets, without encountering air resistance, move at high velocities, eventually forming a dense, fuel-saturated core and jet front. The described character of the fuel jet development is clearly visible in Figure 3, obtained by the optical scanning and threshold segmentation method. Authors of publications have made the assumption to interpret differences in the brightness of fuel jet zones as the size and number of drops in the zone. The results of the performed studies confirmed the adequacy of the assumptions.

Table 1. Physical-chemical properties of fuels

\begin{tabular}{|l|c|c|c|}
\hline \multicolumn{1}{|r|}{ Fuel } & RME & RO & DF \\
\hline $\begin{array}{l}\text { Index } \\
\text { (tempity }\left[\mathrm{kg} / \mathrm{m}^{3}\right]\end{array}$ & $887(15)$ & $917(20)$ & $831(15)$ \\
\hline $\begin{array}{l}\text { Kinematic viscosity }[\mathrm{cSt}] \\
\text { temperature })\left[{ }^{\circ} \mathrm{C}\right]\end{array}$ & $4.48(40)$ & $19.7(60)$ & $1.91(40)$ \\
\hline Freezing point $\left[{ }^{\circ} \mathrm{C}\right]$ & -13 & -23 & -33 \\
\hline Flash point $\left[{ }^{\circ} \mathrm{C}\right]$ & 90 & $>100$ & 57.5 \\
\hline Ash $[\% \mathrm{~m} / \mathrm{m}]$ & 0.009 & - & - \\
\hline Water $[\% \mathrm{~m} / \mathrm{m}]$ & 0.17 & - & 0.0021 \\
\hline $\begin{array}{l}\text { Surface tension }[\mathrm{mN} / \mathrm{m}] \\
\text { at } 50{ }^{\circ} \mathrm{C}\end{array}$ & 29.92 & 31.23 & 25.61 \\
\hline $\mathrm{CN}$ & 54 & 40 & 51 \\
\hline
\end{tabular}

\subsection{Research plan}

Fuel testing by the CDS system was performed at a highpressure fuel pump rotation rate of $875 \mathrm{~min}^{-1}$ (corresponding to the $1750 \mathrm{~min}^{-1}$ rotational speed of the DE); CR system - also when the DE rotational speed corresponds to $n=1750 \mathrm{~min}^{-1}$. In the CDS system, the influence of 
heating $\mathrm{RO}$ to $65^{\circ} \mathrm{C}$ on the characteristics of the fuel jet is estimated. Fuel injection is carried out by a nozzle with an effective total of 4 nozzle holes with cross-section $\mu f=$ $0.21 \mathrm{~mm}^{2}$. The plan of the experiment is shown in Table 2 .

To substantiate the estimates and conclusions made in the course of the research, the materials of the motor DE workflow tests of the authors with CR and CDS fuel supply systems were partially used.

Table 2. The plan of the experiment

\begin{tabular}{|l|c|c|c|c|c|c|c|c|}
\hline \multirow{3}{*}{ Fuel } & \multicolumn{2}{|c|}{ CDS } & \multicolumn{7}{|c|}{ CR } \\
\cline { 2 - 9 } & \multirow{2}{*}{$26^{\circ} \mathrm{C}$} & $65{ }^{\circ} \mathrm{C}$ & \multicolumn{7}{|c|}{ Fuel injection pressure [MPa] } \\
\cline { 4 - 9 } & & & 60 & 80 & 100 & 120 & 140 & 160 \\
\hline $\mathrm{DF}$ & + & - & + & + & + & + & + & + \\
\hline $\mathrm{RME}$ & - & - & + & + & + & + & + & + \\
\hline $\mathrm{RO}$ & + & + & \multicolumn{7}{|c}{-} \\
\hline
\end{tabular}

\section{The results of the study and their discussion}

\subsection{Fuel jet structure dynamics in the CR and CDS system}

The results are shown in Figure $4\left(S_{i} / S\right.$ - the relative share of the i-brightness zone relative to the total area of the fully formed fuel jet).

A characteristic difference in the dynamics of fuel jet structure change in the CR system is the successive transition of zones with large droplets into zones with smaller droplets. Thus, in Figure $4 \mathrm{a}$, the maximum of each subsequent zone as its brightness increases (interpreted as a decrease in the diameter of the droplet) is observed at the time of the disappearance of the previous zone-with a larger droplet diameter (darker zones). Thus, the "transition" of zone 1 into zone 2 ends at $1200 \mu$ s, zone 2 into zone 3 at $1550 \mu \mathrm{s}$, zone 3 in zone 4 at around $2250 \mu \mathrm{s}$. The trend persists with increased fuel injection pressure (Figure 4b). In the CDS system, from the moment of the injection, formation and fuel jet development, zones in

a)

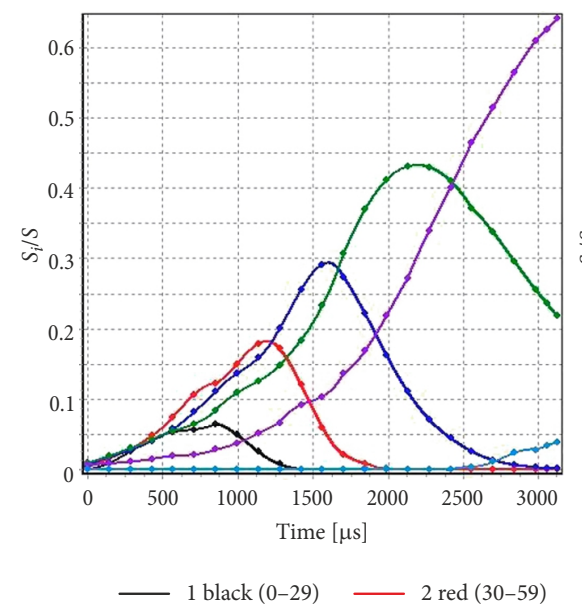

b)

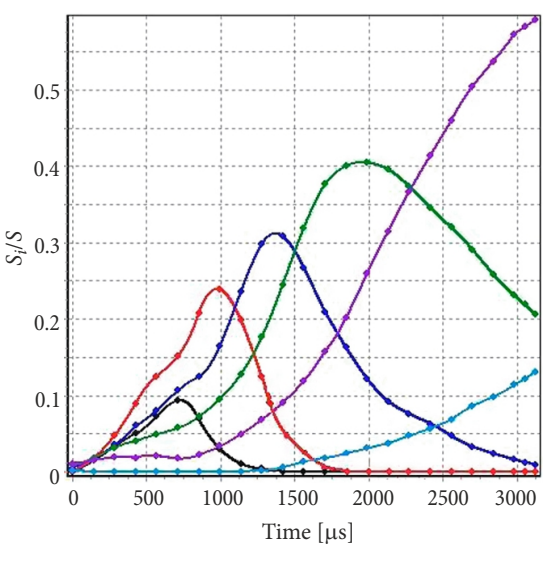

the entire range of the droplet diameter range occur approximately equally (Figure $4 \mathrm{c}$ ).

It is obvious that the traced dynamics of the fuel jet development should significantly affect the difference in the induction period values, as is known, determined by its physical $\tau_{f}$ and chemical $\tau_{c h}$ nature. When the chemical $\tau_{c h}$ nature is equal, the physical $\tau_{f}$ for the CDS system is shorter, since the presence of zones with a small droplet diameter creates more favourable conditions for the evaporation of droplets, the formation of free radicals and the occurrence of autoignition from the injection moment (Lyshevskij 1971; Mollenhauer, Tschöke 2010). Indeed, motor test data showed a 2 -fold difference of $\varphi_{t}$ : $5.3^{\circ} \mathrm{ca}$. by CDS system vs $11 \ldots 12^{\circ} \mathrm{ca}$. by CR system with single-phase injection for the test mode of loading and the magnitude of the cyclic fuel supply.

Increasing the injection pressure in the CR system causes a time shift in the zone transition - the decay of large droplets near the injection start, (Figure $4 \mathrm{~b}$ ), thereby reducing value of $\tau_{i}$. As a result, $\tau_{i}$ is reduced, but significant differences in $\tau_{i}$ are maintained until a pressure increase in CR system to $180 \mathrm{MPa}: 8.5^{\circ} \mathrm{ca}$. vs above-mentioned $5.3^{\circ} \mathrm{ca}$. in CDS fuel supply system.

Intensive single-phase fuel injection in the CR system with a relatively long value of $\tau_{i}$, results in autoignition practically coinciding with the phase of the fuel injection end.

With the observed character of mixture formation and combustion, the controllability of the combustion process is lost, and the phase of kinetic combustion becomes predominant. With such combustion, the most toxic components - nitrogen oxides $\mathrm{NO}_{\mathrm{x}}$ are intensively formed (Reitz, Duraisamy 2015; Baumgarten 2006; Zel'dovich et al. 1980). Obviously, this circumstance should be taken into account by optimizing DE work on various fuels, including when transferring their work into alternative types of fuel - RME and RO. In addition, in practice, in CR system a multi-phase, controlled injection is used, which, in comparison with the CDS system, allows to increase energy and improve ecological characteristics.

c)

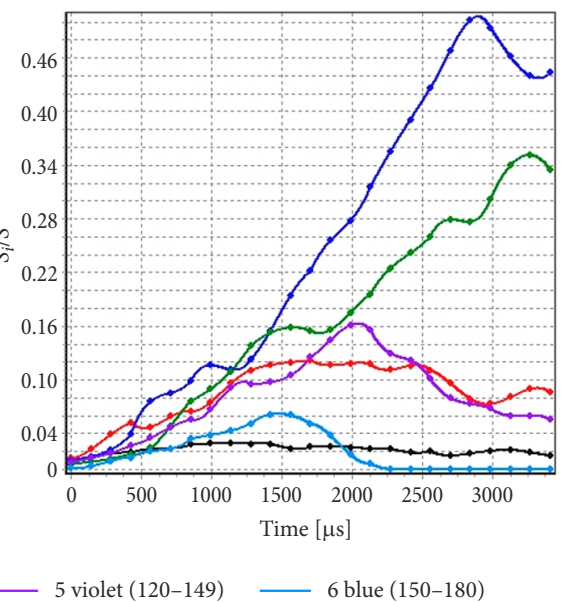

Figure 4 . The structure of the fuel jet: a - CR system (60 MPa); b - CR system $(100 \mathrm{MPa}) ; \mathrm{c}-\mathrm{CDS}$ system $\left(26^{\circ} \mathrm{C}, 1750 \mathrm{~min}^{-1}\right)$ 


\subsection{Fuel jet structure dynamics when transferring DE work from mineral diesel to RME}

Comparison of diesel and RME fuel jet in the CR system, performed in a wide range of injection pressures $P_{f}=$ $60 \ldots 160 \mathrm{MPa}$, allows to give the obtained results and their analysis a great generality. A fragment of the results obtained at $P_{f}=160 \mathrm{MPa}$ is shown in Figure 5 .

In contrast to the dynamics of DF jet structure development discussed above, the nature of RME injection has characteristic differences in the entire investigated range of $P_{f}$ Disintegration of the RME jet into smaller droplets comes $\sim 15 \ldots 30 \%$ faster from the moment of the injection (estimated by the position of the maximum brightness zones). It should be especially noted that structure of the RME jet is less homogeneous and, practically throughout the entire injection, its structure consists of brightness zones 2 through 5 . At the same time, during DF injection, a gradual transition of zones occurs.

As a result, on the one hand, an earlier ignition of the RME should be expected, on the other hand - a smaller fraction of the combustible mixture is prepared for igni-

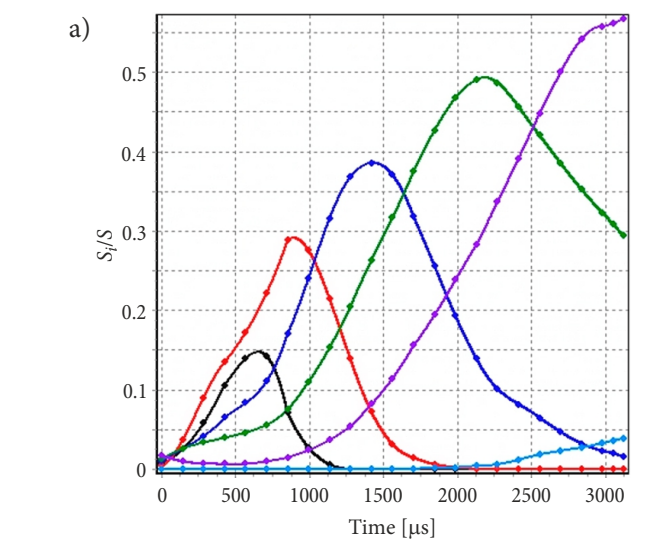

— 1 black (0-29) — 2 red (30-59) — 3 dark blue(60-89) tion compared to DF. Accordingly, we should expect a softer and more controlled combustion process. With this mixture formation, the maximum heat release rates are reached in the diffusion combustion phase, which forms the fuel economy indicators (Hansen et al. 1997; Ma et al. 2015).

The data of motor tests of the authors fully confirm the results of the performed analysis. In particular, in the whole investigated range $P_{f}$, the induction period $\tau_{i}$ for RME is by $1 \ldots 2^{\circ}$ ca. shorter. At this, smaller activation energy (higher $\mathrm{CN}$ ) of RME compared to DF should also be taken into account, since it also causes a reduction in the chemical nature of the induction period $\tau_{i}$. Similar data were obtained in other works (Barradas Filho et al. 2015; Lebedevas et al. 2013; Li et al. 2017).

\subsection{Dynamics of RO jet injection in the CDS system}

Figure 6. shows changes in RO fuel jet structure dynamics, when inlet temperatures of the CDS fuel system highpressure pump are 26 and $65^{\circ} \mathrm{C}$.

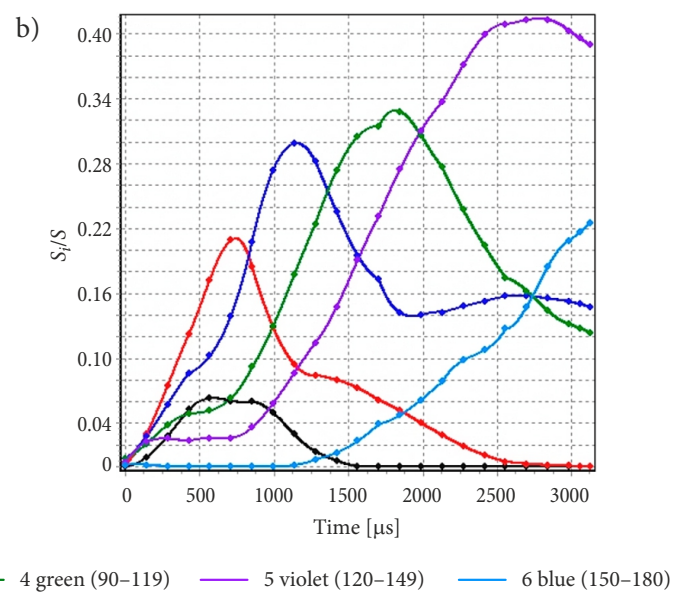

Figure 5. The structure of the fuel jet in CR system: a - DF; b - RME

a)

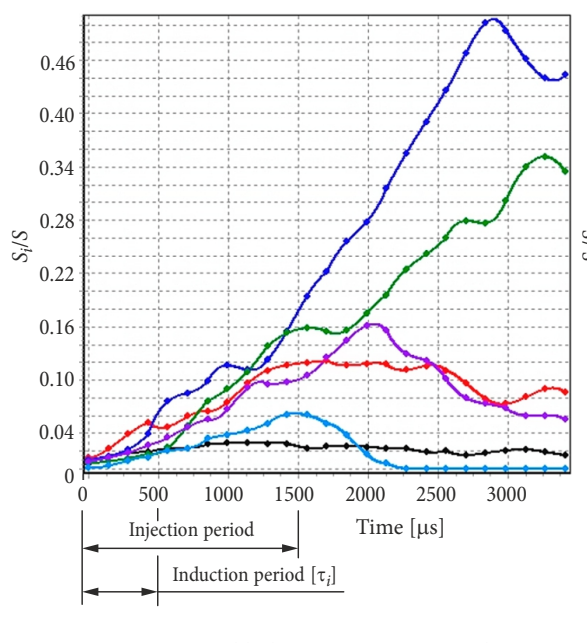

b)

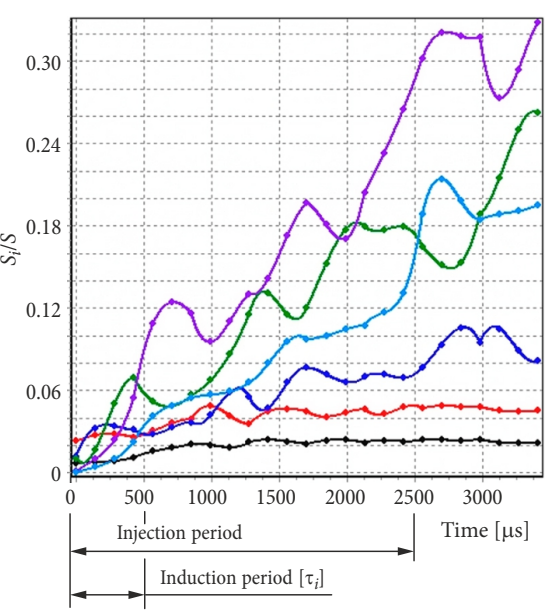

c)

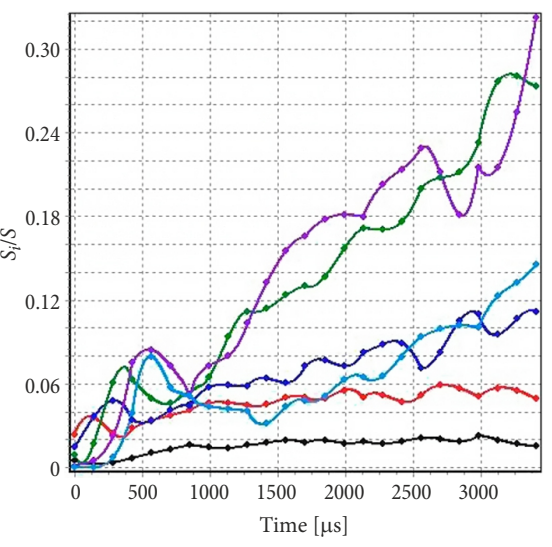

— 1 black (0-29) — 2 red (30-59)

3 dark blue(60-89) — 4 green (90-119)

— 5 violet (120-149) — 6 blue (150-180)

Figure 6. Fuel jet dynamics in the CDS system during injection: a $-\mathrm{DF}\left(26^{\circ} \mathrm{C}\right)$; b - RO $\left(26^{\circ} \mathrm{C}\right) ; \mathrm{c}-\mathrm{RO}\left(65^{\circ} \mathrm{C}\right)$ 
In comparison with diesel (Figure 6a), the total volume of the RO fuel jet has a pulsating character, especially at a temperature of $26^{\circ} \mathrm{C}$. The most unstable zones of the jet are zones with the smallest optical density $-4,5$ and 6 (Figure 6b). In case of preheated inlets to $65^{\circ} \mathrm{C}$ stability of the oil jet structure dynamics significantly improves (Figure $6 \mathrm{c}$ ). This may be due to a reduction in the viscosity of RO from $73 \mathrm{~mm}^{2} / \mathrm{s}$ to $\sim 18 \mathrm{~mm}^{2} / \mathrm{s}$ when it is heated from 26 to $65{ }^{\circ} \mathrm{C}$. For all research options, during the engine tests, almost identical duration of the induction period was obtained $\left(\sim 5^{\circ} \mathrm{ca}\right.$. or $\left.\sim 500 \mu \mathrm{s}\right)$. However, due to the higher $\mathrm{RO}$ viscosity, the injection time is $\sim 65 \%$ greater than with D.

Analysis of the RO fuel jets structure shows that by the end of $\tau_{i}$ the relative proportion of zones with a lower density of fuel droplets $(4,5$ and 6 zones) increases when RO is heated: from $\sim 55$ to $\sim 75 \%$ respectively for 26 and $65^{\circ} \mathrm{C}$. Thus, a more favorable combustion character of preheated RO should be expected. This is confirmed by data from experimental studies (Marchenko et al. 2005).

\section{Promising directions of optical scanning method application}

The research results indicate the adequacy of the method application when performing a qualitative comparative analysis of various design variants of injection systems for diesel and alternative fuels.

At the same time, certain additions to the method application make it possible to pass from qualitative to quantitative estimates of the fuel jet structure development dynamics. In addition, they can be useful for supplementing mathematical models of intra-cylinder processes in DEs.

So, with the assumption that the zones of different optical density of the fuel jet are interpreted as characteristics of fineness and uniformity of spraying, it becomes possible to estimate the expected spectrum of fuel droplet sizes and their development in the injection time.

For this purpose, using the known analytical dependencies grounded on integrated injection parameters, for example, for marine diesels (Lyshevskij 1971), or later studies (Lyshevskij 1981), the average diameter of the fuel droplets $d_{k}$ for the fuel supply process is determined. Thus, on the basis of a generalization of the experimental material by criterial dependencies, the analytical dependence of $d_{k}$ is obtained (Lyshevskij 1971):

$$
\frac{d_{k}}{2 \cdot a}=3.01 \cdot(\rho \cdot W e)^{-0.266} \cdot M^{0.073}
$$

where: $a$ - jet radius at the nozzle outlet; $\rho$ - fuel density; $W e=\frac{w^{2} \cdot \rho \cdot 2 \cdot a}{\sigma}-$ Weber number; $M=\frac{\mu^{2}}{\rho \cdot d \cdot \sigma}-$ criterion $\mathrm{M} ; w$ - jet velocity; $\sigma$ - surface tension; $\mu$ - dynamic viscosity; $d$ - nozzle diameter.

Determination of the Equation (1) parameters by optical scanning method and laboratory tests of the phys- icochemical properties of fuels do not present difficulties.

Similar definitions of $d_{k}$ are proposed by other researchers (Hiroyasu 1985; Lefebvre, McDonell 2017; Dos Santos, Moyn 2011).

By the method of threshold segmentation, the fuel jet is divided into a finite number of brightness zones (in the performed studies -6 zones). Therefore, the average brightness is determined using finite differences:

$$
A_{\text {avr }}=\frac{\sum_{j=1}^{m} \sum_{i=1}^{n} A_{i} \cdot S_{i}}{\sum_{j=1}^{m} \sum_{i=1}^{n} S_{i}},
$$

where: $A_{i}$ - the brightness of the $i$-th zone at the $j$-th time of the injection; $S_{i}$ - the relative area of the $i$-th brightness zone at the $j$-th time of the injection.

Using $d_{k}$ and $A_{a v r}$, the conversion coefficient of the brightness zones during the fuel jet development in the appropriate range of fuel droplets diameters is calculated:

$$
X=\frac{d_{k}}{A_{a v r}} \text {. }
$$

Using the $X$ coefficient, the values of the fuel jet are calculated into the distribution of the corresponding $d_{i}$ values.

\section{Using the method in the computational studies of internal combustion engine}

Modern mathematical models, including multi-zone models (Kuleshov 2004; Kolade et al. 2004), use the average fuel droplets diameter as input data for the fuel injection characteristics and injection process calculation.

At the same time, the spectrum of the fuel droplets diameter dynamically changes during the injection time. It would be advisable to take these changes into account when modelling the processes of mixture formation. Obviously, in order to achieve this it is necessary to have an analytic dependence of homogeneity and fineness parameters changes in the fuel jet, in other words - spectrum of fuels droplet size dynamic changes as a function of the fuel delivery time.

The analysis of the obtained data, as well as the data from other studies (Pimentel 2006), confirm the correspondence of the fuel droplets spectrum at any time to the normal distribution law of the probability density:

$$
f(x)=\frac{1}{\sigma \cdot \sqrt{2 \cdot \pi}} \cdot e^{\frac{(x-m)^{2}}{2 \cdot \sigma^{2}}}
$$

where: $\sigma$ - standard deviation; $m$ - median.

The values of $\sigma$ and $m$ obtained during research are generalized by the analytical dependencies as a function for the fuel jet development time. They can also complement the mathematical modelling methods of the DE workflow. 


\section{Conclusions}

Comparative studies of the fuel jet structure of mineral diesel and biodiesel (RME and RO) have been carried out using optical scanning method for the CDS and CR with single-phase injection fuel supply systems. The obtained data allow predicting the probabilistic changes in the characteristics of the mixture formation at the design stage when transferring the DE for operation on alternative fuels:

1. The structure of the diesel jet in the CDS compared with $\mathrm{CR}$ is much more heterogeneous in size and number of droplets. The presence of less fuel saturated zones from the beginning of injection contributes to a relatively short induction period $5^{\circ} \mathrm{ca}$. and the subsequent favourable heat release characteristic. With single-phase fuel supply in the CR system, a consecutive occurrence and transition of zones with a higher fuel density into a zone with a lower fuel density is observed. As a result, a 2 -fold longer induction period of fuel ignition $11 \ldots 12^{\circ} \mathrm{ca}$. is observed. Therefore, in practice, in CR system a multi-phase, controlled injection is used, which, in comparison with the CDS system, allows to increase energy and improve ecological characteristics.

2. Using RME in the CR system in comparison with DF increases the heterogeneity of the fuel jet, thereby substantiating the observed reduction of the induction period by $1 \ldots 2^{\circ} \mathrm{ca}$. in the entire investigated range of injection pressures $60 \ldots 160 \mathrm{MPa}$. As a result, the parameters of the working process dynamics are reduced and a more favourable character of mixture formation and combustion should be expected, which contribute to an increase of the indicated efficiency during operation with RME in comparison with $\mathrm{D}$, which is also confirmed in practice.

3. The structure of the fuel jet $\mathrm{DF}$ and $\mathrm{RO}$ in the initial phase of injection in the CDS system is practically the same, contributing to almost the same duration of the induction period $\sim 5^{\circ} \mathrm{ca}$. At the same time, the injection of a previously unheated RO is accompanied by fluctuations in the shape and structure of the jet. Heating to $65{ }^{\circ} \mathrm{C}$ stabilizes the structure of the fuel jet and increases the proportion of less fuelsaturated zones, which contributes to reducing the induction period and the injection duration.

4. Promising directions of using the optical scanning method in the mathematical modelling methods of the DE workflow are proposed.

\section{References}

Ashgriz, N. 2011. Handbook of Atomization and Sprays: Theory and Applications. Springer US. 935 p. https://doi.org/10.1007/978-1-4419-7264-4

Barradas Filho, A. O.; Barros, A. K. D.; Labidi, S.; Viegas I. M. A.; Marques, D. B.; Romariz, A. R. S.; De Sousa, R. M.; Marques, A. L. B.; Marques, E. P. 2015. Application of artificial neural networks to predict viscosity, iodine value and induction period of biodiesel focused on the study of oxidative stability, Fuel 145: 127-135.

https://doi.org/10.1016/j.fuel.2014.12.016

Baumgarten, C. 2006. Mixture Formation in Internal Combustion Engines. Springer-Verlag Berlin Heidelberg. 294 p.

https://doi.org/10.1007/3-540-30836-9

Dos Santos, F.; Le Moyn, L. 2011. Spray atomization models in engine applications, from correlations to direct numerical simulations, Oil \& Gas Science and Technology - Revue d'IFP Energies nouvelles 66(5): 801-822.

https://doi.org/10.2516/ogst/2011116

EC. 2005. Communication from the Commission: Biomass Action Plan. $\operatorname{COM(2005)~} 628$ final. 7.12.2005. Brussels. 47 p. Available from Internet: https://eur-lex.europa.eu/legal-content/ EN/TXT/?uri=celex:52005DC0628

EC. 2009. Directive 2009/28/EC of the European Parliament and of the Council of 23 April 2009 on the Promotion of the Use of Energy from Renewable Sources and Amending and Subsequently Repealing Directives 2001/77/EC and 2003/30/EC. 47 p. Available from Internet:

http://data.europa.eu/eli/dir/2009/28/oj

EC. 2011. White Paper: Roadmap to a Single European Transport Area - Towards a Competitive and Resource Efficient Transport System. COM(2011) 144 final. 28.3.2011, Brussels. Available from Internet: https://eur-lex.europa.eu/legal-content/EN/ ALL/?uri=CELEX:52011DC0144

EN 14214:2009. Automotive Fuels. Fatty Acid Methyl Esters (FAME) for Diesel Engines. Requirements and Test Methods.

Es'kov, A. V.; Gibel'gauz, S. I. 2011. Laboratornyj praktikum. Issledovanie dinamiki razvitiya strui raspylennogo dizel'nogo topliva. Barnaul. 36 s. (in Russian).

Es'kov, A. V.; Kulmanakov, S. P.; Sagalakov, A. M.; Maeckij, A. V.; Kiryushin, I. I. 2014. Issledovanie processov smeseobrazovaniya $\mathrm{v}$ dizele s primeneniem opticheskogo kontrolya kachestva raspylivaniya topliva, Vestnik Altajskoj nauki (1): 287-291 (in Russian).

GOST R 52368-2005 (EN 590:2009). Toplivo dizel'noe EVRO. Tehnicheskie usloviya [Diesel Fuel EURO. Specifications] (in Russian).

GOST R 53457-2009. Maslo rapsovoe. Tehnicheskie usloviya [Rapeseed Oil. Specifications] (in Russian).

Hansen, U.; Strenziok, R.; Schröder, T. 1997. Demonstration project for the use of rape methyl ester in ecologically sensitive aquatic areas, P. Chartier, G. L Ferrero, U. M Henius, S. Hultberg, J. Sachau, M. Wiinblad (Eds.). Biomass for Energy and the Environment, 1707-1712.

https://doi.org/10.1016/B978-0-08-042849-9.50044-6

Hiroyasu, H. 1985. Diesel engine combustion and its modeling, in COMODIA 1985: the 1st International Symposium on Diagnostics and Modeling of Combustion in Internal Combustion Engines, 4-6 September 1985, Tokyo, Japan, 53-75.

Kegl, B.; Kegl, M.; Pehan, S. 2008. Optimization of a Fuel Injection System for Diesel and Biodiesel Usage, Energy \& Fuels 22(2): 1046-1054. https://doi.org/10.1021/ef700657g

Kerker, M. 1969. The Scattering of Light and Other Electromagnetic Radiation. Academic Press. 688 p. https://doi.org/10.1016/C2013-0-06195-6

Klyus, O.; Labeckas, G.; Slavinskas, S.; Mažeika, M. 2013. Raspredelenie kapel' v processe raspylivaniya dizel'nogo topliva i ego smesi s biokomponentami, Scientific Journals of The Maritime University of Szczecin 108(36.2): 93-97. (in Russian).

Klyus, O.; Zamiatina, N. 2017. Residual fuel atomization process simulation, Combustion Engines 169(2): 108-112.

https://doi.org/10.19206/CE-2017-219 
Kolade, B.; Morel, T.; Kong, S. 2004. Coupled 1-D/3-D analysis of fuel injection and diesel engine combustion, SAE Technical Paper 2004-01-0928. https://doi.org/10.4271/2004-01-0928

Krause, P.; Klyus, O. 2013. Ispol'zovanie parametra poverhnostnogo natyazheniya dlya ocenki processa raspylivaniya topliva v dizelyah, Scientific Journals of the Maritime University of Szczecin 36(108) 2: 98-101. (in Russian).

Kuleshov, A. S. 2004. Programma rascheta i optimizacii dvigatelej vnutrennego sgoraniya DIZEL'-RK. Opisanie matematicheskih modelej, reshenie optimizacionnyh zadach. MGTU im. N. Je. Baumana, Rossiya. 123 s. (in Russian).

Kulmankov, S. P.; Lebedevas, S.; Sinitsyn, V.; Lebedeva, G.; Kulmankov, S. S.; Yakovlev, S. 2016. The influence of the fuel spray structure and dynamics of its formation on surface combustion of biofuels in diesel engines, Transport 31(1): 84-93. https://doi.org/10.3846/16484142.2015.1071279

Kulmanakov, S. P.; Matievskij, D. D.; Balashov, A. I.; Lebedevas, S. V. 2009. Perspektivnye smesevye kislorodosoderzhashhie topliva, Polzunovskij vestnik (1-2): 17-21 (in Russian).

Kulmanakov, S. P.; Sinicyn, V. A.; Drobyshev, O. V. 2012. Issledovanie struktury i dinamiki razvitiya toplivnoj strui dlya tradicionnogo i biotopliva pri ispol'zovanii razlichnyh sistem toplivopodachi, Dvigateli vnutrennego sgoraniya (1): 13-18 (in Russian).

Labeckas, G.; Slavinskas, S. 2009. Comparative performance of direct injection diesel engine operating on ethanol, petrol and rapeseed oil blends, Energy Conversion and Management 50(3): 792-801.

https://doi.org/10.1016/j.enconman.2008.09.029

Lebedevas, S.; Vaicekauskas, A.; Lebedeva, G.; Kulmanakov, S. P.; Shashev, S. 2006a. The change of operational characteristics of diesel engines running on RME biodiesel. Parameters of thrust and fuel economy, in Transport Means 2006: Proceedings of the 10th International Conference, 19-20 October 2006, Kaunas, Lithuania, 229-233.

Lebedevas, S.; Vaicekauskas, A.; Lebedeva, G.; Matijevskij, D.; Kulmanakov, S. 2006b. The change of operational characteristics of diesel engines running on RME biodiesel. Emission of exhaust gases, in Transport Means 2006: Proceedings of the 10th International Conference, 19-20 October 2006, Kaunas, Lithuania, 161-166.

Lebedevas, S.; Lebedeva, G.; Žaglinskis, J.; Rapalis, P.; Gudaityte, I. 2013. Research of characteristics of working cycle of highspeed diesel engine operating on biofuels RME-E and DRME-E. Part 2. Indicators and characteristics of heat release in diesel cylinder, Transport 28(3): 217-223.

https://doi.org/10.3846/16484142.2013.828652

Lefebvre, A. H.; McDonell, V. G. 2017. Atomization and Sprays. CRC Press. 300 p.

Lewińska, J.; Kapusta, Ł. J. 2017. Analysis of the microstructure of the fuel spray atomized by marine injector, Combustion Engines 169(2): 120-124. https://doi.org/10.19206/CE-2017-221

Li, B.; Li, Y.; Liu, H.; Liu, F.; Wang, Z.; Wang, J. 2017. Combustion and emission characteristics of diesel engine fueled with biodiesel/PODE blends, Applied Energy 206: 425-431. https://doi.org/10.1016/j.apenergy.2017.08.206

Li, T.; Nishida, K.; Hiroyasu, H. 2011. Droplet size distribution and evaporation characteristics of fuel spray by a swirl type atomizer, Fuel 90(7): 2367-2376.

https://doi.org/10.1016/j.fuel.2011.03.011

Linne, M. 2013. Imaging in the optically dense regions of a spray: a review of developing techniques, Progress in Energy and Combustion Science 39(5): 403-440.

https://doi.org/10.1016/j.pecs.2013.06.001
Linne, M.; Paciaroni, M.; Hall, T.; Parker, T. 2006. Ballistic imaging of the near field in a diesel spray, Experiments in Fluids 40(6): 836-846. https://doi.org/10.1007/s00348-006-0122-0

Lyshevskij, A. S. 1971. Raspylivanie topliva v sudovyh dizelyah. Leningrad: Sudostroenie. 248 s. (in Russian).

Lyshevskij, A. S. 1981. Sistemy pitaniya dizelej. Moskva: Mashinostroenie. 216 s. (in Russian).

Ma, F; Zhao, C.; Zhang, F.; Zhao, Z.; Zhang, Z.; Xie, Z.; Wang, H. 2015. An experimental investigation on the combustion and heat release characteristics of an opposed-piston foldedcranktrain diesel engine, Energies 8(7): 6365-6381.

https://doi.org/10.3390/en8076365

Marchenko, A. P.; Minak, A. F.; Semenov, V. G.; Lin'kov, O. Yu.; Shpakovskij V. V.; Oboznyj, S. V. 2005. Raschetnojeksperimental'nye issledovaniya po ocenke vlijaniya podogreva al'ternativnyh topliv na pokazateli raboty dizelya, Dvigateli vnutrennego sgoraniya (1): 8-17 (in Russian).

Markov, V. A.; Devyanin, S. N.; Bykovskaya, L. I. 2013. Optimizaciya sostava mnogokomponentnyh smesevyh biotopliv dlya dizel'nyh dvigatelej sel'skohozyajstvennyh mashin, Izvestiya vysshih uchebnyh zavedenij: Mashinostroenie (12): 51-63 (in Russian).

Markov, V. A.; Devyanin, S. N.; Semenov, V. G.; Shahov, A. V.; Bagrov, V. V. 2011. Ispol'zovanie rastitel'nyh masel $i$ topliv na ih osnove $v$ dizel'nyh dvigatelyah. OOO NIC Inzhener, Rossiya. 536 s. (in Russian).

Mollenhauer, K.; Tschöke, H. 2010. Handbook of Diesel Engines. Springer-Verlag Berlin Heidelberg. 636 p. https://doi.org/10.1007/978-3-540-89083-6

Pastor, J. V.; Payri, R.; Salavert, J. M.; Manin, J. 2012. Evaluation of natural and tracer fluorescent emission methods for droplet size measurements in a diesel spray, International Journal of Automotive Technology 13(5): 713-724. https://doi.org/10.1007/s12239-012-0070-z

Pimentel, R. G. 2006. Measurement and Prediction of Droplet Size Distribution in Sprays. PhD Thesis. Laval University, Canada. 305 p. https://doi.org/110.13140/RG.2.1.1224.5841

Reitz, R. D.; Duraisamy, G. 2015. Review of high efficiency and clean reactivity controlled compression ignition (RCCI) combustion in internal combustion engines, Progress in Energy and Combustion Science 46: 12-71.

https://doi.org/10.1016/j.pecs.2014.05.003

Sedarsky, D.; Gord, J.; Carter, C.; Meyer, T.; Linne, M. 2009. Fastframing ballistic imaging of velocity in an aerated spray, $O p$ tics Letters 34(18): 2748-2750.

https://doi.org/10.1364/OL.34.002748

Van de Hulst, H. C. 1981. Light Scattering by Small Particles. Dover Publications. $496 \mathrm{p}$.

Wang, L.; Badra, J. A.; Roberts, W. L.; Fang, T. 2017. Characteristics of spray from a GDI fuel injector for naphtha and surrogate fuels, Fuel 190: 113-128. https://doi.org/10.1016/j.fuel.2016.11.015

Zel'dovich, Ya. B.; Barentblatt, G. I.; Mahviladze, G. M. 1980. Matematicheskaya teoriya goreniya i vzryva. Moskva: Nauka. 480 s. (in Russian).

Zhosan, A. A.; Ryzhov, Yu. N.; Kurochkin, A. A. 2012. Vprysk i gorenie rapsovogo masla i dizel'nogo topliva v sovremennyh dizelyah, Vestnik Orel GAU 1(12): 130-132 (in Russian). 